\title{
Screening for cervical cancer in Hungary: New role for health visitors
}

\author{
Döbrössy Lajos, Kovács Attila, Budai András, Odor Andrea, Fehér Erika \\ National Chief Medical Officer'Office, Budapest, Hungary
}

Correspondence: Döbrőssy Lajos. Address: National Chief Medical Officer'Office, Budapest, Gyáli út 2-6. Hungary H-1097. Email: dobrossy.lajos@oth.antsz.hu

Received: January 23, 2013

Accepted: May 22, 2013

Online Published: May 30, 2013

DOI: $10.5430 / c n s . v 1 n 3 p 32$

URL: http://dx.doi.org/10.5430/cns.v1n3p32

\section{Abstract}

In Hungary, opportunistic cervical screening has a long tradition; having been launched in the mid 1950s. Since 2003, a nation-wide organized cervical screening programme has been in operation. However, the "gatekeepers" of the screening are still the gynaecologists who take the smear for cytological examination along with a complex examination, including colposcopy. The compliance rates are unacceptably low because the difficult access to gynaecological services, particularly in rural areas. Therefore, it has been decided that cervical screening would be added to the job description of district health visitors who are qualified to provide preventive care to the female population. The relevant knowledge and skill necessary to provide cervical screening would be included in the health visitors' curriculum. The early experiences of the feasibility studies are encouraging.

\section{Key words}

Cervical screening, Smear-taking, District health visitors, Education and training

\section{Background}

In Hungary the health status of the population is rather poor; the overall mortality rates are among the highest in Europe ${ }^{[1]}$. The burden of non-communicable chronic disease the population has to carry is particularly heavy. Cancer is the second most common cause of death. Efforts need to be made to decrease the mortality. For the time being, population screening of proved effectiveness seems to be the most promising way of reducing cancer mortality, including cervical cancer. To this effect, a National Public Health Programme has been established in order to initiate various activities in the health field, in particular preventive activities and population screening programmes.

Since it proved its effectiveness in terms of mortality reduction from the target diseases ${ }^{[2]}$, cervical cancer screening is widely accepted as a public health policy in the countries of the European Union. Organized cervical cancer screening programmes as provider-initiated, call-and-recall based population screening, are strongly recommended by international bodies such as the European Council ${ }^{[3]}$, and implemented in 15 of the 27 Member States. ${ }^{[4]}$. In all but a few countries, the screening practice follows the "state-of-the-art" recommendations as stated in the guidelines jointly published by the European Commission and the International Agency for Research on Cancer of the World Health Organization ${ }^{[5]}$. Five out of ten women in the target age group in the European Union (51\%, 55 million) are targeted for cervical cancer screening in 
the countries which have implemented population based screening programmes ${ }^{[4]}$. There are wide variations between the Member States in programme policies regarding the duration of the screening interval and the age of women screened. The strategy adopted in 12 member states is the three yearly screening of the population. This has achieved significant reduction in cervical cancer in several countries ${ }^{[6]}$.

As a rule, smears for cytological examination are taken from the uterine cervix by the primary care personnel, analysed in accredited cytology laboratories, reported back to the primary care, and, if necessary, the patient with positive smears is referred to gynaecological services for further diagnostics and treatment.

Hungary is one of the rare exceptions. Here, the history of opportunistic cervical screening carried out by gynaecologists, using colposcopy as the only screening tool goes back to the mind 1950s. The cytological examination was added a decade later, and a regular training for pre-screener cytotechnologists established ${ }^{[7,8]}$. The "screening" was carried out as a complex gynaecological examination, including colposcopy and smear-taking for cytology.

In the 1980 's, there had been sufficient capacity to screen the eligible women population, and a "cervix programme" was declared. In this decade, the number of women screened in the way described above was rather high and so was the number of cytology smears analysed. The clinical stages of detected cervical abnormalities have favourably shifted, the survival time of detected cancer cases extended, but the mortality rates had not decreased. Hence even such an extensive opportunistic screening has not reached its goal. The reason for failure was perceived to be the lack of individual identification of the women screened: only the number of smears taken was registered, and nobody knew who was and who wasn't screened.

In the meantime, the health authorities established a National Public Health Programme, in which the screening modalities of proved effectiveness (cervix, breast, colorectal) have been incorporated. The cervical screening protocol has been reorganised in line with the international "state-of.-the-art" guidelines in which the cytological examination is the sole screening tool. However, the current standard of practice is difficult to change. The current screening protocol represents a compromise between the above described traditional "gynaecological screening" and the internationally recommended organised screening process in such a way that the eligible women receive a personal invitation letter advising them to see a gynaecologist for smear-taking; the gynaecologist sends the smear to a cytology laboratory for analysis, receives back the test-report, and takes care of the patient accordingly. Practically, the gynaecologists have remained the "gatekeepers" of screening.

According to this protocol, the nation-wide organized cervical screening programme, covering the entire female population between 25 and 65 years of age, advises screening every three years, was launched in 2003 . However, the early experiences with the invitation-based "call-and-recall" organised programme are unfavourable, because the gynaecologists continue taking smears, and the majority of the women receive screening in the traditional way, i.e. outside the organized, provider initiated programme. As a result, the compliance rates registered by the National Screening Registry are unacceptably low.

Analysis of the reasons for non-attendance of the offered screening showed that the limited access to the smear-taker gynaecological services presents the main difficulty to overcome. This is particularly true for women in rural areas, the relatively long distances the invited women need to travel to seek out gynaecologists, and the "discomfort" of the procedure prevents them from participating. To improve the low compliance and to comply with the recommendations of the Hungarian National Audit Office, the health government (Ministry of Human Resources) and the management responsible for implementation of the screening (National Chief Medical Officers' Office) has decided to attempt to improve the access to screening facilities by intensifying the involvement of primary care personnel, especially the "health visitors" in the screening process. 


\section{The network of Health Visitors in Hungary}

In Hungary, the Health Visitor System has been in operation since 1915. The Hungarian word for health visitor: "védőnő" literally means "health protector" (In other countries this kind of health professional might be named "public health nurses," or "social workers"). Chief health visitors are posted at the national level, and in the counties within Hungary, as well in order to supervise the network of the district health visitors working in rural areas.

\section{Traditional role of district health visitors}

The "health visitors" are professionals receiving higher education, i.e. four years following the secondary high school graduation. Their traditional role is to promote physical, mental and social well-being of the families. They are qualified to provide preventive care to the families, the female population, in particular. Health visitors are specialized in women's health, the mother, infant and child care, and health protection of adolescents. They focus on family planning, caring for pregnant women by providing periodic "check-ups" during pregnancy and preparing them for child-birth and motherhood. The health visitors hold counselling hours in their offices, visit families at their place of residence, organise group-meetings on various subjects such as breastfeeding, and bring together women for local health promoting programmes (e.g, Women's Health Day). They organise immunisation programmes, and various screening examinations for infants and children as well as providing preventive services in the kindergartens and schools. Part of their task is focused on health promotion and health education informing and advising people about healthy lifestyles.

Their activities have been organized in primary care level, particularly in districts, i.e. in smaller administrative units with populations less than 5000, i.e., taking care of some 250 resident families each. They work in collaboration with local primary care physicians and in close relationship with their target population. This offers an ideal setting for the intended role for the district health visitors.

In Hungary, just like in many developed countries, there is a demographic crisis: the birth rates are getting lower and lower. As a consequence, the working capacity of the health visitors is not fully utilized. This is one reason why the health management has decided to set a new role for the health visitor, putting their close relationship with the target population of cervical screening to good use. The health visitors have easy access to women who have difficulties in seeking gynaecological services in rural areas.

\section{New role for the district health visitors}

In relation to cervical screening, the district health visitors have been given the following tasks:

- they can personally contact women invited by an invitation letter issued by the National Screening Registry;

- they can motivate and encourage less educated women of lower socioeconomic status to accept the invitation and participate in cervical screening. They can pay particular attention to women who have never attended a screening;

- they have the golden opportunity to provide women with necessary pre-screening information on both the benefits and potential harms of screening, helping them to arrive at an "informed decision," which is an ethical imperative ${ }^{[9]}$;

- they can take smears for cytological examination (Pap-smear), and send the smears to centralized cytology laboratories for analysis;

- the test results are sent back to district health visitors for follow up: $(*)$ if the result is negative, they instruct the woman to turn up at the regular scheduled screening in three years time, or $\left(^{*}\right)$ they advise women to see 
gynaecological services if the smear shows inflammation, or $\left(^{*}\right)$ they strongly advise the patient to seek gynaecological services if the result is suspect or positive for any abnormality (malignancy) for diagnosis and treatment;

- the personal contact provides an opportunity for the health visitors to provide health education, to give personally tailored advice to the women with regard to healthy lifestyle. In this way, they can carry out primary preventive and health promoting activities, as well.

\section{Education and training}

The prerequisite for participation was to equip health visitors' offices with gynaecological instruments needed for smear taking, and, IT tools necessary to report the test results and the follow-up data to the central screening registry.

The aim of the educational session is to acquaint the candidates with all aspects of the prevention of cervical cancer, and to provide knowledge on all necessary aspects of screening for the target disease. The requirements were two-fold.

First, they are expected to have up-to-date knowledge on

- anatomy of the uterine cervix;

- natural history and pathology of the cervical cancer and its precursors;

- the basic principles of organized screening;

- the cytological examination, classification of the smears, and those of the follow-up of patients with non-negative test results;

- factors that have influence on compliance with the offered screening;

- psychological side-effects of screening, and how to avoid them, and;

- referral routes of patients with cervical abnormalities.

Second, health visitors are familiarized with the modern methods of effective communication with healthy women. Here, they must learn communicative tools for gently providing unfavourable information, too.

The training sessions have been arranged in one of the offices of the gynaecological service under the supervision of an experienced gynaecologist. The aim was to gain skills in smear taking. One is pronounced skilful if thirty good quality smears are obtained as judged by a competent cytologist.

The National Chief Medical Officer's Office prepared teaching materials for both education and training for the health visitors and provided all necessary support for the trainees.

After having completed the education and training programmes, the candidate received a "certificate of competency" issued by the Health Authorities that authorize them to carry out screening activities in their localities.

In order to prepare health visitors for their task, the National Chief Medical Officer's Office organized education and training sessions for a pilot programme. 


\section{Preliminary results of the pilot programmes}

In order to demonstrate the feasibility of the concept, it has been tested in 4 month "pilot programmes" in 2011. During this period, 235 district health visitors volunteered to participate in the education and training sessions, and 181 of them (77\%) agreed to take part in the fieldwork.

In the three pilot programmes 101,874 eligible women received an invitation letter issued by the National Screening Registry. The health visitors received the list of those invited, and made personal contact with 51,399 women (51\%). The rest of the invited women rejected the offered screening for various reasons (e.g. has a smear in the past 3 years, prefer to be screened by gynaecologist etc.).

Smears taken by the health visitors were sent to a central cytology laboratory. As to the quality, the smears were qualified on a 1 to 6 scale, the optimal being 24 point; on this scale the candidates have achieved an average of 21,4 point (89\%), as "highly satisfactory". The most frequent error was the lack of endocervical cells in the smear; in this case, the smear-taking had to be repeated.

All in all, 15 cervical cancer cases $(0.04 \%)$ have been detected and verified. The experiences with the pre-screening information and post-screening "follow-up" were considered satisfactory.

In one of the counties (Nograd) the screening procedure was completed with a questionnaire survey (sample size was 451 screened women). To the question: "Why did you attend cervical screening by health visitor?" the answers were the following:

- screening was available locally without travelling a remote place $(87 \%)$;

- $\quad$ confidence in the local health visitor $(72 \%)$;

- $\quad$ received proper pre-screening information (54\%); smear was taken by a female (42\%);

- precise appointment was given, no waiting time (55\%).

The early experiences with the pilot programme are encouraging. It has been proved that the district health visitors can acquire the knowledge and skill necessary to carry out large scale cervical screening. They can establish contact with the eligible women in their district, and persuade most of them to accept the offered screening.

\section{Discussion}

In Hungary, provider-initiated organised cervical screening programme has been in operation since 2003. The procedure has been regulated by a standard protocol, published by the Chief Medical Officer ${ }^{[10]}$. The population list - provided by the database of the National Health Insurance Fund Administration - serves as the notification list, the basis for personal invitation. The eligible women are invited by name, and re-invited in case they fail to attend. If any cervical abnormality is detected by cytological examination, the woman is referred to gynaecological services for further examination in order to rule out, or to verify and treat the detected abnormality. This practice is in line with the international recommendation.

However, in Hungarian practice the clinical gynaecological examination and the cervical screening of the population have merged ${ }^{[11]}$. Historically, the gynaecologists have played a key role in the screening process by taking smear themselves, in addition to colposcopy and a complex gynaecological examination. Such a "complex" examination of any other parts of female genitalia other than uterine cervix (including the endocervical canal) is not a method of proved effectiveness from the point of view of cervical screening; therefore it does not make any sense from a public health viewpoint. This procedure might be clinically justified, but does not fit the public health agenda. Furthermore, gynaecologists, with some 
notable exceptions, seems to insist on this "traditional" but obsolete practice, and do not report the screened cases and test results to the National Screening Registry. This is why the registered attendance rates are much lower as compared with the number of women screened in the health care system, outside the organise screening programme. As a consequence, the National Health Insurance Fund Administration paid for 960.000 smears taken from 850.000 women as "gynaecological diagnostic cytology" (OENO Code 29.601), as compared with 40.520 smears originating from organised screening programme (OENO Code 42.700) ${ }^{[12]}$.

This is why the health authority has decided to reorganize the screening programme as a public health measure, and, to make use of the district health visitors' capacity in population screening. However, the early experiences are limited because of the very short duration of the pilot screening programme, but its results are encouraging: the health visitors are able to meet the requirements of their new role in the cervical screening process, and, the majority would be ready to take the extra workload to improve care. Experience shows that their involvement is well received by the female population, and they can motivate participants to accept the offered screening. Therefore, the health government has decided to go further, and to institutionalise the district health visitors' role in population screening, and, to arrange the inclusion of smear-taking and patient' follow-up into the health visitors' job description.

However, there is a long way to go: "bad habits die hard". First of all, the regular education and training of the health visitors must take place. At present, there are almost 4.000 health visitors in the health care system in the country, hence the most urgent need is to properly train them. This would be only possible if the five Faculties of Health Sciences attached to the Medical Schools where health visitors are trained and educated, actively participated in the "postgraduate" training. Further, it is essential to make arrangements to regularly include the relevant knowledge and skill in the curriculum of the faculties. At the same time, the health visitors' competency needs to be extended, and the cervical screening of the population has to be included in their job description.

What could make cervical screening work in Hungary? By now, a country-wide organised cervical screening system capable of regular screening of all eligible women has been developed. The cytology capacity, management and information system are in place, but are not utilised. However, our hands are tied by the traditional way of screening: the insistence by the gynaecological community on their "historical role" seems to be a major obstacle to carry out an effective screening programme; the current rather high mortality rates $(5,2 / 100.000)$ need to be reduced. Making use of properly trained health visitors to reach the underserved women seems to be a promising way of "breaking through".

We strongly believe that active involvement of the district health visitors in the cervical screening would give an additional chance of early detection of the cervical cancer in Hungary, for the population benefit, and in this way, we can approach the "European standard" in the field of cervical screening.

\section{References}

[1] International Agency for Research on Cancer. Global Cancer Fact sheet. 2008. Available from: http://globocan.iarc.fr/factsheets/cancers/all.asp

[2] Läära E, Day NE, Hakama M. Trends in mortality from cervical cancer in the Nordic Countries: association with organized screening programmes. Lancet. 1987; 1(8544): 1247-9. http://dx.doi.org/10.1016/S0140-6736(87)92695-X

[3] Council of the European Union: Council recommendation of 2 December 2003 on cancer screening(2003/878/EC). Official J Europ. Union. 2003;373(46): 34-8.

[4] European Commission. Cancer Screening in the European Union. Repoert on the implementation of the Council recommendation on cancer screening. First report. IARC. Lyon. 2008.

[5] European Commission. European guideline for quality assurance in cervical cancer screening. 2nd. ed. IARC. 2008.

[6] Peto J, Gilham C, Flechter O, Matthews FE. The cervical cancer epidemic that screening has prevented in the U.K. Lancet. 2004; 364(9430): 249-56. http://dx.doi.org/10.1016/S0140-6736(04)16674-9 
[7] Döbrőssy L. [Five decade of cervical screening in Hungary]. A méhnyakszürés öt évtizede Magyarországon. Nőgyógy Onkol. 2007; 12 (1):5-9. Hungarian.

[8] Kovács A, Döbrőssy L, Budai A, Cornides Á. [The state of the organized cervical screening programme in Hungary in 2006]. A népegészségügyi méhnyakszürés helyzete Magyarországon 2006.ban. Orv. Hetil. 2007;148(12): 535-40. Hungarian. PMid:17444018 http://dx.doi.org/10.1556/OH.2007.28075

[9] Austoker J. Gaining informed consent for screening. Brit. Med J. 1999; 319(7212): 722-23. PMid:10487983 http://dx.doi.org/10.1136/bmj.319.7212.722

[10] Döbrőssy L(ed). [Organised screening in oncology. Guidelines for quality assurance in screening]. Szervezett szürés az onkológiában. Minőségbiztosítási kézikönyv és módszertani útmutató. Min. Health. 2000. Hungarian. PMid:10964496

[11] Döbrőssy L, Kovács A, Budai A, Cornides Á. [Gynaecological cancer screening or cervical screening? Conflict of clinical and public health viewpoints]. Nőgyógyászati rákszürés, vagy méhnyakszürés? Klinikai és népegészségügyi nézőpontok ütközése. Orv. Hetil. 2012; 153(33):1295-1306. Hungarian. PMid:22890177 http://dx.doi.org/10.1556/OH.2012.29432

[12] Kovács A, Döbrőssy L, Budai A, Boncz I, Cornides Á. Cervical screening in Hungary: why does the "English model” work but the "Hungarian model" does not? Eur J Gynaec Oncol. 2007; 29 (1): 5-9. 